\title{
INTERACTION BETWEEN LANDSCAPES AND COMMUNITIES \\ IN THE NEOLITHIC: MODELING SOCIOECOLOGICAL CHANGES IN NORTHEAST-HUNGARY BETWEEN 6000-4500 BC
}

\author{
ANDRÁs FüZESI \\ Hungarian Archaeology Vol. 8 (2019), Issue 3, pp. 1-11, https://doi.org/10.36338/ha.2019.3.1
}

During the millennia, the relationship of man and environment was constantly transformed. Due to sedentary lifestyle and food production, the impact of human communities on the environment was multiplied exponentially since the Neolithic period. This activity created a new phenomenon, the cultural landscape, which was, however, not simply a product of human agency, but became an ,independent” agent, affecting its creator. The complexity of this relationship can be recognized all the time, not only in our everyday lives - thinking for example, on the global economic and social consequences of climate change-but also in archaeological assemblages. The project outlined in this paper explores the impact of Neolithic communities in Northeastern Hungary on the landscape. It focuses on three research themes-settlement (settlement network), economy (land-use) and communication (interactions among communities)—covering different aspects of the same problem: the interaction and mutual transformation of human communities and landscapes.

Landscape archaeology has moved to the forefront of the international and Hungarian research as well, owing its success to two trends. First, environmental awareness and protection of the environment are increasingly appreciated globally, turning both public opinion and experts towards this topic. Second, this field of study allows a great deal of latitude for interdisciplinarity, as it needs cooperation between natural and life sciences and humanities (MüLLER, 2018). The landscape approach offers particularly useful analytic and interpretive perspectives for archaeology: instead of a rigid spatial and temporal framework, this view focuses on dynamic relationship networks. Among the scholars who fostered the landscape paradigm shift, Tim Ingold and his 'taskscape' model has to be emphasized. Ingold had centered his approach on the processes of landscape formation, which in turn led to the recognition of temporal and other overlapping aspects of the landscape along the spatial one in the interpretative space, for example, the ecological, cultural, economic and symbolic landscapes (INGOLD, 1993). Among these different aspects of the landscape, a host of connections exists, sprouted from the societies that created those landscape phenomena. These relationships have been recognized a long time ago (see the archaeological culture model of ClARKE, 1968), but we can truly assess the traces of their coexistence and entanglement only nowadays, with the advent of the entanglement and complexity theories, with network analysis and agent-based modeling ${ }^{1}$ (Chapman, 2009; HODder, 2012; KNAPPETT, 2013; Wurzer, et al., 2015) (Fig. 1).

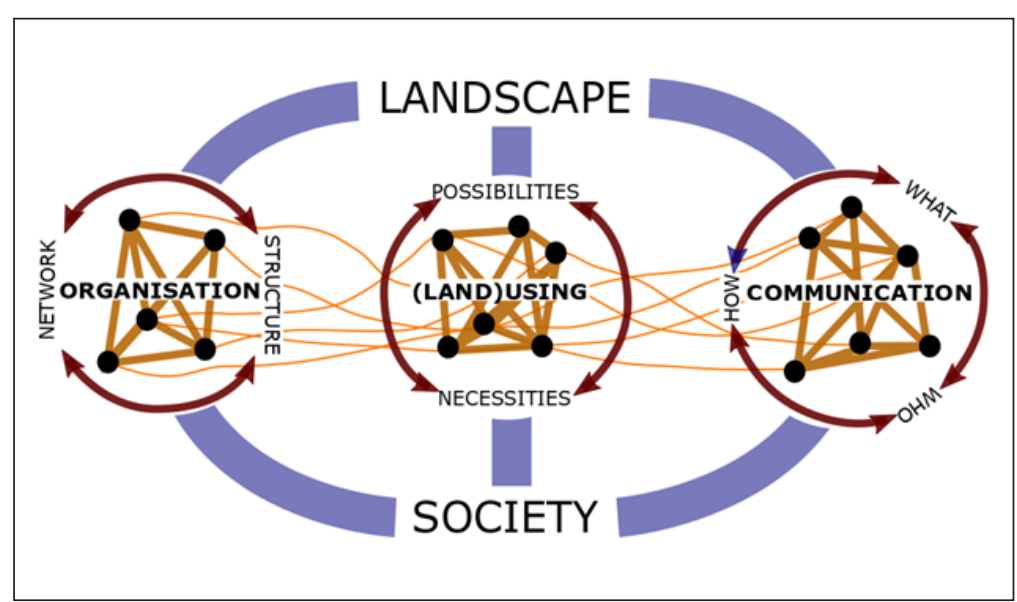

Fig. 1. Socioecological models link the subfields of settlement organization, land-use, and social communication. Study of the networks on which these components built is realized by statisticalgeospatial analysis.

\footnotetext{
Agent based modeling is a computer simulation, which explores the activities and interactions of individuals and groups, measuring their impact on the system as a whole (WuRzer, et al., 2015).
} 
András Füzesi - Interaction between Landscapes and Communities in the Neolithic

Post-processual and p-archaeology ${ }^{2}$ brought a theoretical reconfiguration in archaeology (GosDEN\&MALAFOURIS, 2015), accompanied by a methodological change, with increasingly robust and precise data acquisition, management and use for statistics (DrENNAN, 2009). These developments highlighted the issues concerning Middle Range Theory, the ways of connecting primary data and higher-order theories together (RAAB\&GOODYEAR, 1984). Complex analyses, such as modeling socioecological change, are permeated by these issues in many regards. The intertwined economic, social and cultural processes reveal themselves differently in different archaeological artifact collections, resulting in uneven research data quality. The introduction of Bertalanffy's system theory in archaeology ${ }^{3}$ granted more holistic management of data acquired by subfields of the discipline. Up-to-date modeling highlighted previously unrecognized systemic relationships (KoHLER, 2012). Although archaeological data have not got equal relevance beyond their original context of recovery, the interaction between landscape and society is almost always prevalent in more encompassing studies. Statistical analysis of a well-organized database can offer appropriate conclusions about data relationships, which serves as a

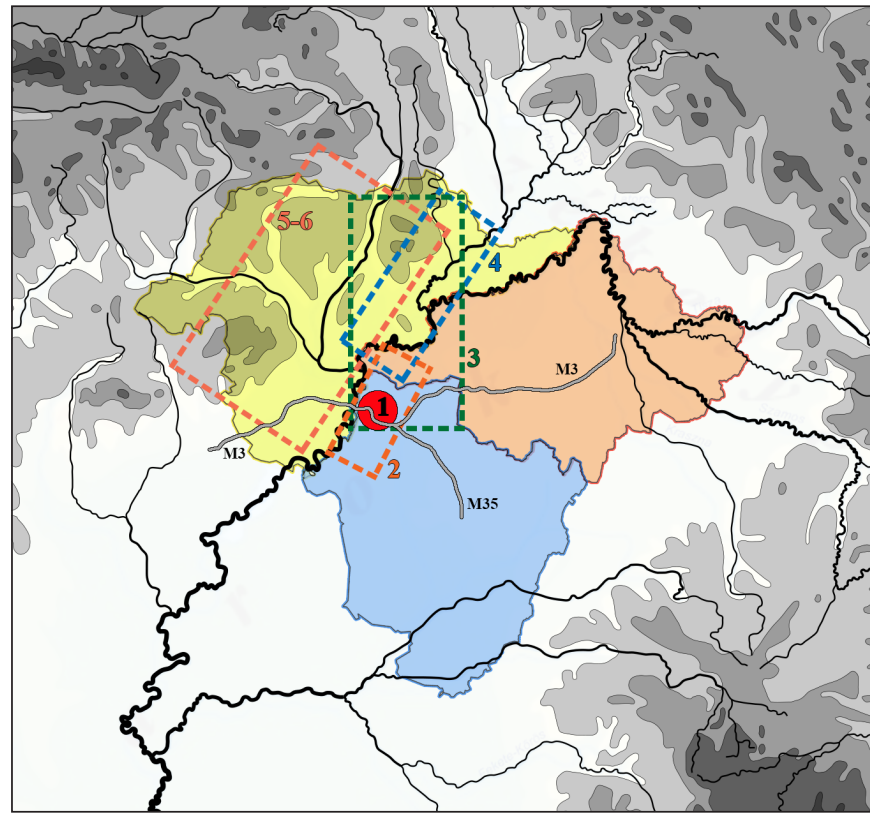

Fig. 2. Research projects into the Neolithic period in Northeastern Hungary. 1. Polgár Island microregion; 2. Preventive surveys and excavations in the region of Polgár (RACZKY - ANDERS 2009, FÜZESI 2009, 2016); 3. Upper Tisza Project (CHAPMAN et al 2010); 4. Late Neolithic settlements in Northeastern Hungary Ph.D. dissertation (KovÁCS 2013b); 5. Middle Neolithic archaeological sites in Borsod-AbaújZemplén county, Ph.D. dissertation (CSENGERI 2014); 6. Late Neolithic sites of Borsod-Abaúj-Zemplén county, MA thesis (HAJDÚ 2014). base for modeling socioecological change.

Northeastern Hungary played a crucial role in the Neolithization process, which reached Central Europe from the Balkans. Whereas, it continued to expand from Transdanubia into different parts Western- and Central Europe, the communities of the Great Hungarian Plain spread into a much more restricted area (KozŁowski, 2009). Despite this relative isolation, these groups developed intensive relationships across the region and beyond, which resulted in an extremely diverse material culture (SHERRATT, 1982; RACZKY\&ANDERs, 2003; Siklósi, 2013).

Polgár Island is a prominent micro-region in this area, which had been investigated by the ELTE Institute of Archaeological Sciences since 1989. The researches were carried out in the frames of preventive excavations prior to the construction of the M3 and M35 motorways, and were aided by Hungarian and international research projects, operating both at micro-regional and regional scales (Fig. 2). The decades-long study provides appropriate data and methods for complex modeling (RACZKY\&ANDERS, 2009; 2012; Anders\&Raczky, 2013; SeböK, et al., 2013; Raczky, et al., 2015; FüZESI, et al., 2016; FARAGó, 2018). The core area of our study stretches between Tiszadob, Tiszavasvári and Tiszacsege towns. The artifacts were collected there during excavations at the Neolithic sites and field walks since 1990 (Fig. 3). Since several of our research questions require a wider perspective, (and the quantity of the available data is insuffi-

\footnotetext{
2 Post-processual archaeology developed in response to problems raised by processual archaeology. Instead of generalizing views, it is characterized by investigations of individual examples and contexts, as well as by a structuralist and critical approaches. P-Arch, i.e. Process Archaeology, focuses on the the emergence of archaeological phenomena, to understand the processes behind them (GosDen \& Malafouris, 2015).

3 The general systems theory of Ludwig von Bertalanffy describes systems on the basis of interrelations among its components. The concept of open systems, as defined by Bertalanffy, allows for modelling the activities of biological entities, including human societies (KoHLER, 2012).
} 
András Füzesi - Interaction between Landscapes and Communities in the Neolithic

cient), we extended the scope of our study to already published datasets (archaeological and ecological) from the counties of Borsod-Abaúj-Zemplén, Szabolcs-Szatmár-Bereg and Hajdú-Bihar.We plan to approach the social and ecological transformations of Neolithic communities between 6000-4500 BC in Northeastern Hungary along three themes, namely: settlement, land-use patterns, and communication. Both the environmental setting and the social relationships of these communities affected these aspects, albeit at different rates.

\section{TRACES OF NEOLITHIC SOCIAL ORGANIZATION IN THE SETTLEMENT SYSTEM AND SETTLEMENT STRUCTURE}

The sedentary lifestyle was a defining characteristic of Neolithic communities; hence, the archaeology of their settlements provides fundamental information about these communities. Neolithic settlement forms have undergone a series of structural changes during the millennia. The differentiation between central and satellite settlements and the appearance of tells were the most important developments (RACZKY, 2015). Themes of studies (above the level of individual settlements) concern systemic relations among the settlements, while on the settlement level, research concentrates on structural patterns (building concentrations, rows of dwellings, etc.) and particular types of settlements and features (MAKKAY, 1982; Sherratt, 1982; Chapman, 1989; RaczKy, 2006; DomboróczKi, 2009). Systemic and structural patterning, as well as their often asynchronous temporal evolution may point to social developments. The structure and functioning of Neolithic communities had been defined by groups at intermediary levels of social organization (between the individual and society), such as the household, a well-established entity in the social sciences (KALla, 2013).

Since 2012, systematic surveys have been carried out according to a uniform methodology, including the application of geographical information systems (Fig. 4). Although previous projects were also collecting such data about the micro-region, they employed various other methods, and this calls for a common ground for data interoperability, particularly in cases where the surveys cannot be repeated.

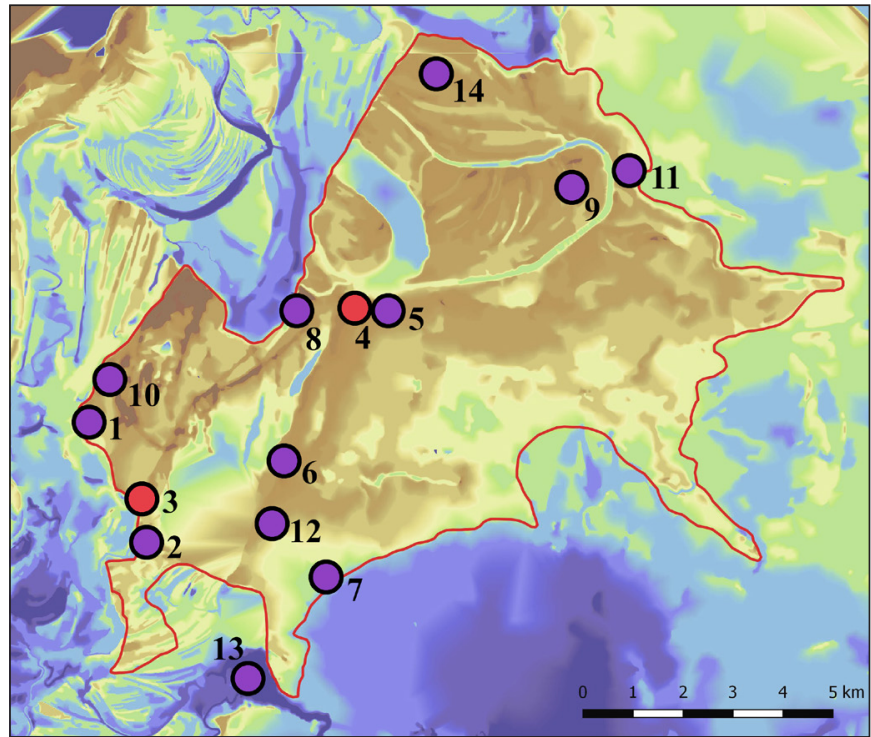

Fig. 3. Archaeological excavations at Neolithic sites in the region of Polgár Island (after RACZKY - ANDERS 2009).

1. Polgár-Ásott-halom, 2. Polgár-Basatanya, 3. PolgárBosnyákdomb, 4. Polgár-Csöszhalom, 5. Polgár-Csőszhalomdülö, 6. Polgár-Ferenci-hát, 7. Polgár-Kása halmi-dülö, 8.

Polgár-Kenderföldek, 9. Polgár-Kenygel-köz, 10. PolgárKirály-érpart, 11. Polgár-Nagy Kasziba, 12. Polgár-Piócásidülö, 13. Folyás-Szilmeg, 14. Újtikos-Demeterkút.

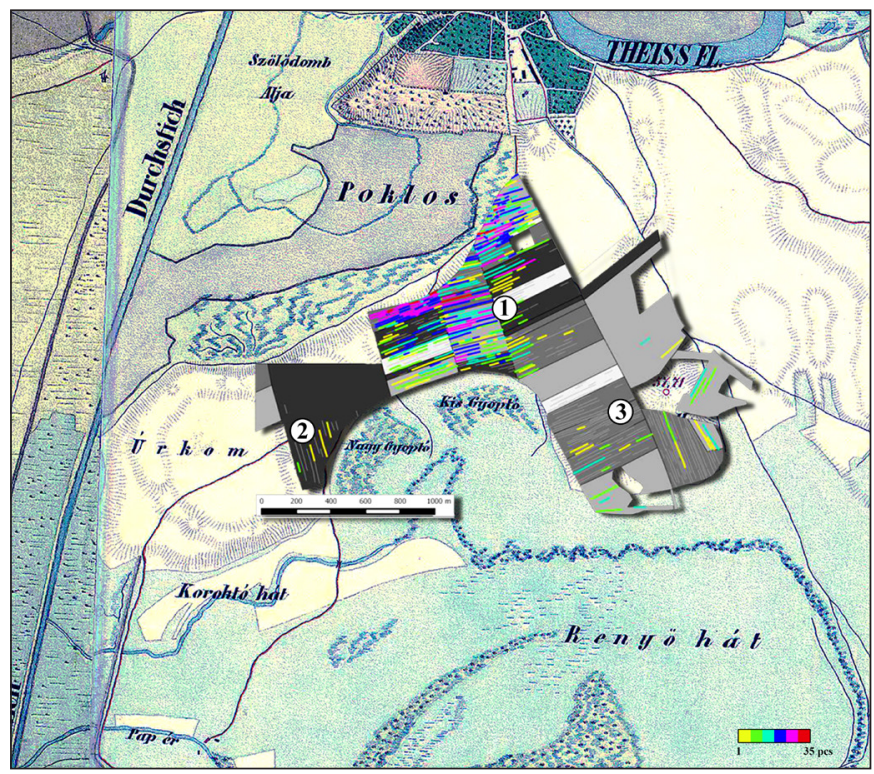

Fig. 4. Identification of satellite settlements (2-3) by field walking in the vicinity of a Late Neolithic main site Tiszadob-Poklos (1). The GPS-recorded locations render the findings into data collecting cells, drawing a more precise picture about the extent and intensity of the site (grey polygons indicate research suitability, colored lines refer to the number of ceramic fragments registered in the collecting cells).

Based on previous researches, it is possible to reconstruct the micro-regional development of the settlement system (Domboróczki, 2009; RACZKy\&ANDERs, 2009; Füzesi, 2009; 2016; FüZesI, et al., 2016). Soon 
András Füzesi - Interaction between Landscapes and Communities in the Neolithic

after settlement in the pioneer phase (AVK1), a connected system had come into being, in which bigger and continuously inhabited settlements took central functions on. These communities brought about satellite settlements, in order to exploit their environment more effectively (DomboróczKI, 2009). Until the Late Neolithic, this integration process intensified, central places appeared, consisting of a tell and a horizontal settlement with a considerable size (Fig. 5), surrounded by satellites, as practiced before (FüZESI, et al., 2016). In a regional perspective, this micro-regional model represents only one element of a more diverse overall picture. Our research grasps these micro-regional differences in order to map socioecological changes.

\section{LAND USE AS THE INTERSECTION OF ENVIRONMENTAL POTENTIAL AND ECONOMIC NEEDS}

Constrained by the knowledge and natural environment of the communities, subsistence economy was of primary importance in Neolithization (GRONENBORN\&Petrasch, 2010). Several fields of study, such as archaeozoology and archaeobotanics, provide information for the study of agricultural practices and needs (BöKÖNYI, 1988). Examination of these two aspects, along supply and demand, helps to reconstruct past economic behavior (VÖRös, 1994; GÁL, et al., 2005). Site-catchment analysis measures environmental assets and potential (HigGS\&VITA-FINZI, 1970), by the identification of resources that can be reached within a one-hour walking distance (a five-kilometer radius) from the settlement. Comparison between particular site catchments reveals differences in the economic potential of communities (FüZESI, 2009). Our research aim is not to reconstruct the Neolithic environment, but to analyse land-use, based on already published reconstructions (RACZKY, et al., 2002; MAGYARI, et al., 2012; Moskal-DEL-Hoyo, et al., 2018).

In the frames of the UTP, John Chapman attempted to draw up a land-use model (CHAPMAN, et al., 2010), however, his work focused on food production only. Subsistence activities constitute a more complex topic. For instance, riparian forests (Fig. 6) did not only offer pasturage for livestock, but their native wildlife was also a source of food and raw materials (Vörös, 1995; GÁL, et al., 2005;

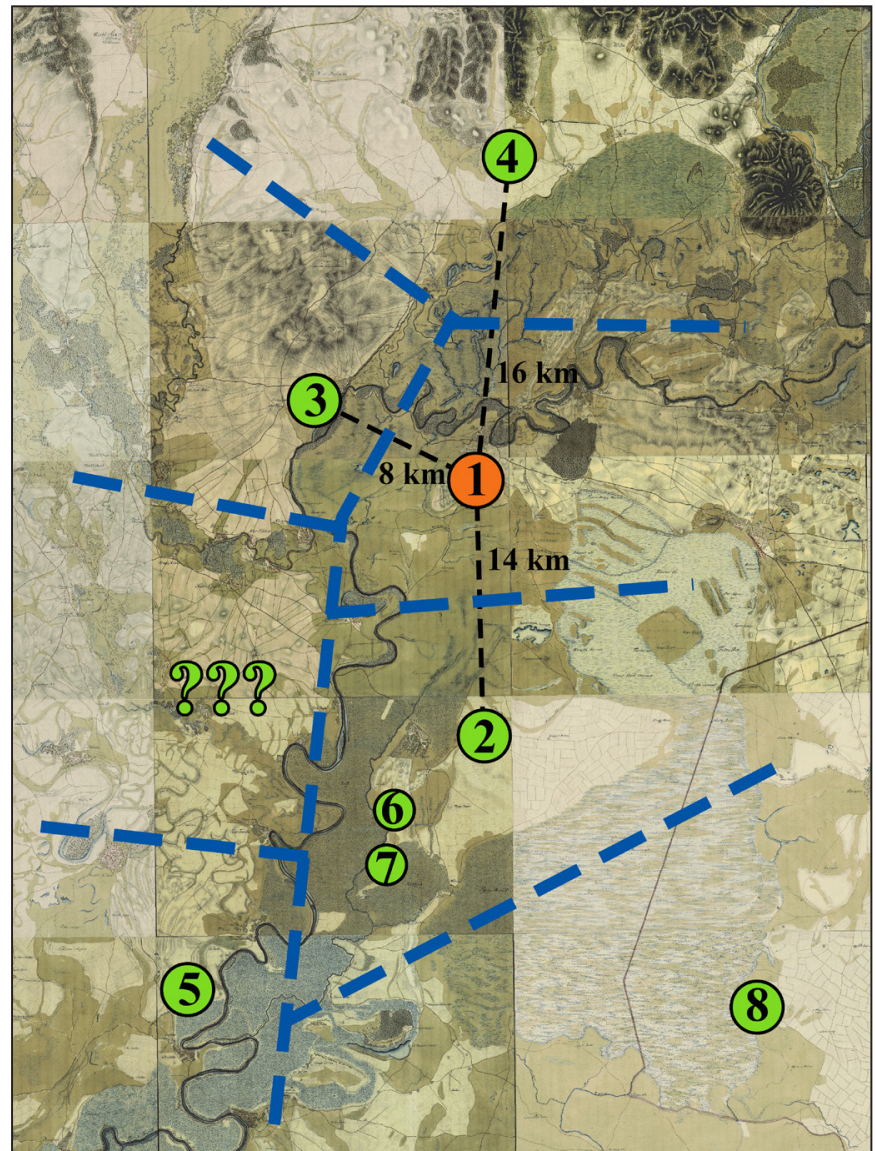

Fig. 5. Location of Tiszadob-Poklos among the central places, in the Late Neolithic settlement system along the river Tisza. 1. Tiszadob-Poklos, 2. Polgár-Csőszhalom, 3. Tiszalúc-Vályogos, 4. Szerencs-Taktaföldvár, 5. TiszakesziSzódadomb, 6. Polgár-Bosnyákdomb, 7. Folyás-Kígyósdomb, 8. Hajdúböszörmény-Pródi halom.

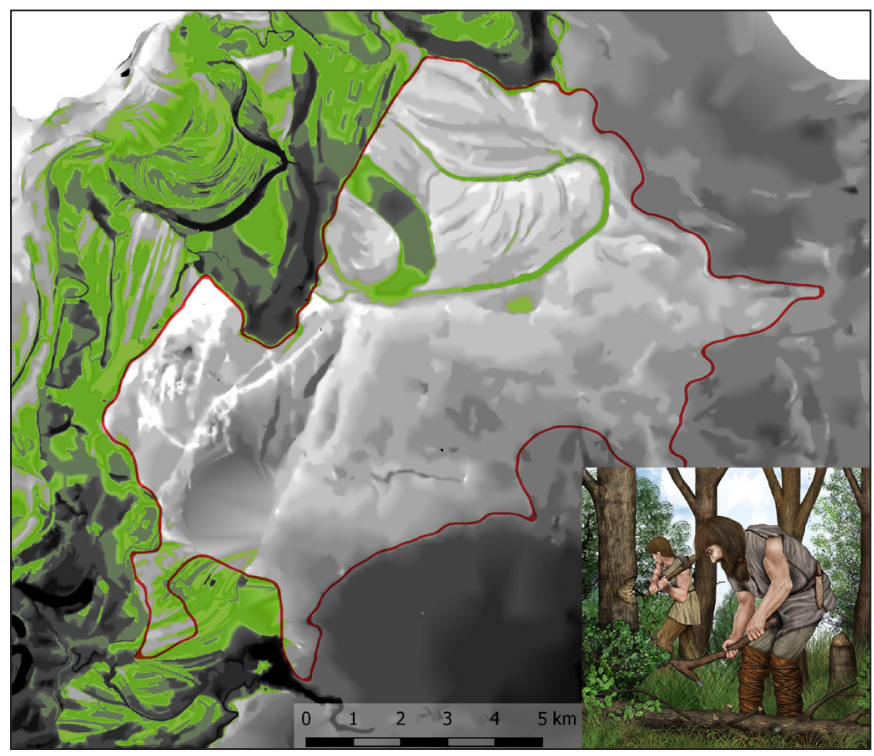

Fig. 6. 1. Riparian forest of hardwood trees around the Polgár Island (after Raczky et al 2002). 2. Slashing of riparian forests with prehistoric methods favored the formation of coppices, affecting the quality of wood available for use. 
András Füzesi - Interaction between Landscapes and Communities in the Neolithic

GYULAI, 2010). The widespread use of these resources for tool manufacture (RACZKY, et al., 2015) and building construction (BITTNER, 2016) points to the intricate relationship between man and environment. Our research project aims to explore the manifold land-use patterns, the transformations of economic activities with the passage of time, and the effects of transformations on the communities.

\section{COMMUNICATION AS A VEHICLE IN THE FORMATION OF SYMBOLIC AND SOCIAL LANDSCAPES}

One of the achievements of the Neolithization Revolution was pottery. Ceramic vessels, as excessively used artifacts, were produced by various techniques, and in a bountiful supply of forms. They are the most determinant finds on Neolithic archaeological sites; besides their primary (practical) functions, pottery was used in various other functions. With their varied decorations, ceramic containers were also included in the repertoire of tools used for intra- and intergroup communication, which, according to anthropological and ethnographical examples, already had numerous settings, levels, and means of display. Nevertheless, ceramics remained the most readily accessible source for past communication, accessible for archaeological research (ORTON, et al. 1995; PEChTL, et al., 2015). The communicative role of their decorations, the individual and group identities displayed in their styles, the mentalities encoded in decoration patterns can be grasped with the help of Design Structure Analysis, as a complex analytical tool (WASHBURn\&CROWE, 1988; ArNOLD, 2010; SEBÖK, 2018).

Our analysis concerns the various decoration techniques and the spatiotemporal development of the increasingly complex patterns applied in case of Neolithic ceramic styles. The aim is to identify the various kinds of group identities that manifest themselves in the sphere of communication during the Neolithic period. A special focus of this research is the analysis of anthropomorphic representations, which can be studied on examples from Northeastern Hungary. Pál Raczky and Alexandra Anders draw attention to differences in the distribution patterns of face pots and ceramic styles during the Middle Neolithic. The artifacts were carrying extraordinary identity and their distribution also point to a special network (RACZKY\&ANDERS, 2003). The authors analyzed two characteristic elements, the so-called arched- and M-motifs, but the artifacts display numerous other decorative elements as well. The more detailed evaluation of these motifs may shed light on the methods of communication and/or connections of ritual communities in Neolithic society, at micro-regional (Fig. 8) and macro-regional scales (Fig. 9). Comparing the results of this study to patterns of lithic raw material circulation (BIRÓ, 1998), and to reconstructions concerning the

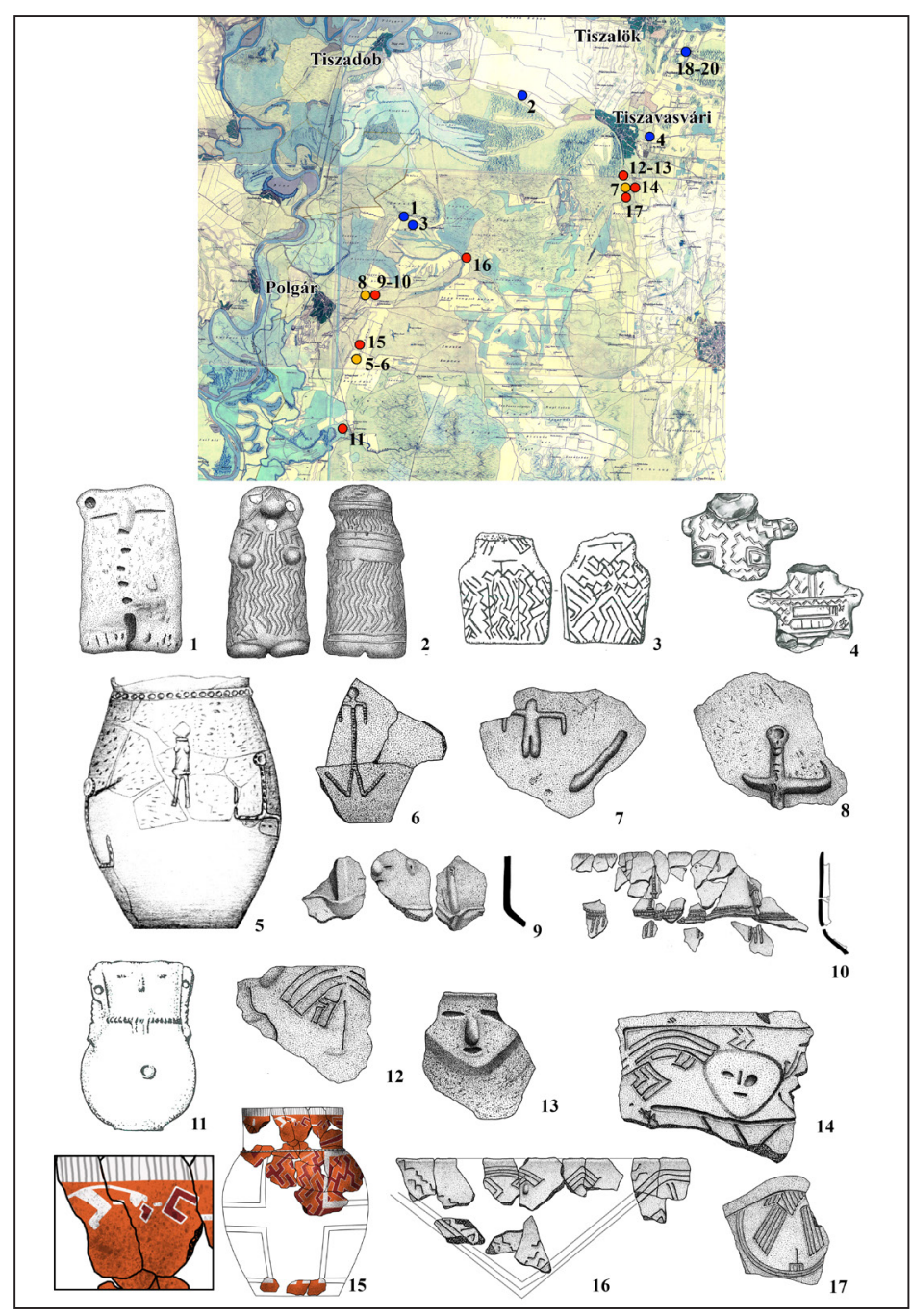

Fig. 7. Late Neolithic figural representations from Polgár Island. The idols (blue), reliefs (yellow) and face pots (red) differ from each other not only in their types but in their details of forming and in the applied motifs. This variability points to the complex character and connection networks of the microregion. (Numbers identify the artifacts and sites. The drawings are not on the same scale.) 
András Füzesi - Interaction between Landscapes and Communities in the Neolithic

directions of trade as reflected based by the import of raw materials and artifacts (Kovács, 2013a), will be instrumental for understanding the motivations of the Neolithic communities to use different modes of communication.

Socioecological modeling implements individual developmental models about different social phenomena and the datasets they rest upon (STROBEL, 1997; Raczky, 2006; DomboróczKi, 2009), into a unified frame of interpretation. This inquiry has an effect on a region in Hungary, where decades-long fieldwork, primer, and further specialized analyses paved the way for the archaeological application of complex modeling and simulation. Following the recognition of causal relations between the elements, after weighting their statistical significance, we will able to create such a detailed model that conforms to the models already used in theoretical archaeology.

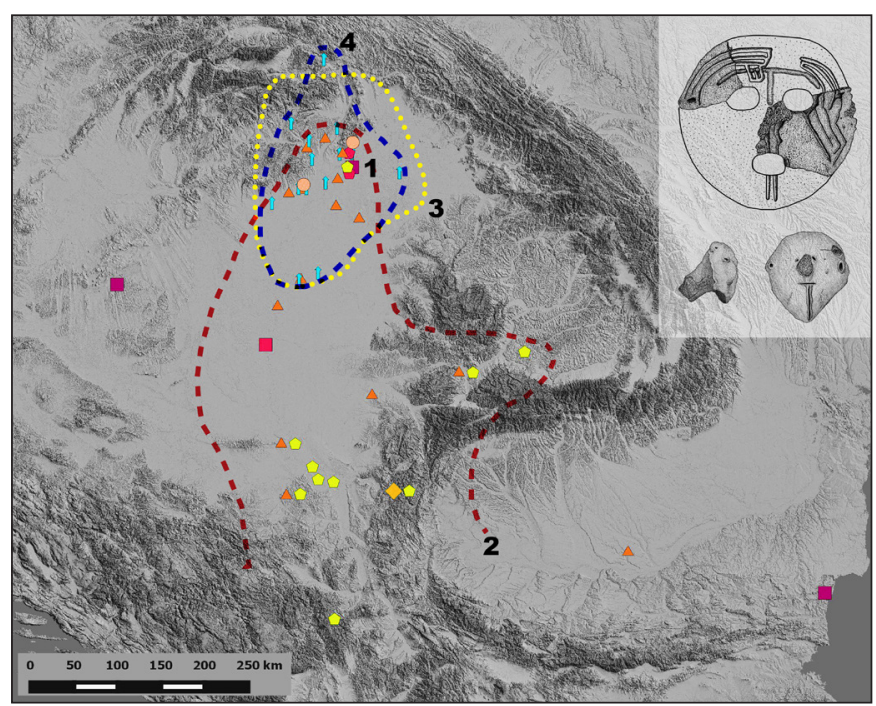

Fig. 8. Middle Neolithic mask and fragments of idols with mask (1) from Tiszalök-Hajnalos (after Füzesi 2018). The mask and its representations (2) imply southern connections with the Balkans. The arched motif on the mask (3) and the T-motif on the idol heads (4) mirrors regional traditions of the Upper Tisza.

The project is funded by the Postdoctoral (PD) scholarship program of the National Research, Development and Innovation Fund (ID no. 129323: title: 'Interaction between landscapes and communities in the Neolithic: modeling socioecological changes in Northeast-Hungary between 6000-4500 BC').

\section{REFERENCES}

Anders, A. \& Raczky, P., 2011.

Háztartások települési egység viszonya Polgár-Csőszhalom késő neolitikus lelőhelyén / The relation between households and settlement units at the Late Neolithic settlement of Polgár-Csőszhalom. Ösrégészeti Levelek - Prehistoric Newsletter, Volume 13, pp. 78-101.

ArNold, D. E., 2010.

Design structure and community organization in Quinua, Peru. In: D. K. Washburn, ed. Structure and Cognition in Art. Cambridge: Cambridge University Press, pp. 56-73.

BIRÓ, K. T., 1998.

Lithic Implements and the Circulation of Raw Materials in the Great Hungarian Plain during the Late Neolithic Period. Budapest: Hungarian National Museum.

BITTNER, B., 2016.

A bedőlt falak néma falak? A lenyomatos paticsok vizsgálatának lehetőségei a késő neolitikumban az Alföldön. The fallen walls are silent walls? The possibilities of imprinted daub research in the Late Neolithic Hungarian Plains. Tisicum, Volume 25, pp. 33-40.

BöKÖNYI, S., 1988.

Környezeti és kulturális hatások késö-neolitikus kárpát-medencei és balkáni lelöhelyek csontanyagán. Akadémiai székfoglaló, 1986. Budapest: Akadémiai kiadó. 
András Füzesi • Interaction between Landscapes and Communities in the Neolithic

Chapman, J., 1989.

The early Balkan village. In: S. Bökönyi, ed. Neolithic of Southeastern Europe and its Near Eastern Connections. International Conference 1987, Szolnok - Szeged. Budapest: Institute of Archaeology of the Hungarian Academy of Sciences, pp. 33-53.

Chapman, J., Gillings, M., Magyari, E., Schiel, R., Gaydarska, B., \& Bond, C., 2010.

The Upper Tisza Project. Studies in Hungarian Landscape Archaeology. Book 2: Settlement Patterns in the Bodrogköz Block. Oxford: Archaeopress.

Chapman, R., 2009.

Archaeologies of Complexity. London - New York: Routledge. doi: https://doi.org/10.4324/9780203451779

Clarke, D., 1968.

Analytical Archaeology. London: Methuen. doi: http://dx.doi.org/10.7312/clar90328

CSEngeri, P., 2014.

Late groups of the Alföld Linear Pottery culture in north-eastern Hungary. New results of the research in Borsod-Abaúj-Zemplén County. Dissertationes Archaeologicae, 3(2), pp. 501-517.

DOMBORÓCZKI, L., 2009.

Settlement Structures of the Alföld Linear Pottery Culture (ALPC) in Heves County (North-Eastern Hungary): Development Models and Historical Reconstructions on Micro, Meso and Macro Levels. In: J. K. Kozłowski, ed. Interactions between Different Models of Neolithization North of the Central European Agro-Ecological Barrier. Krakow: Polish Academy of Arts and Sciences, pp. 75-127.

Drennan, R. D., 2009.

Statistics for Archaeologists. A Common Sense Approach. New York - London: Springer. doi: http://dx.doi. org/10.1007/978-1-4899-0165-1

FARAGÓ, N., 2018.

Polgár-Csőszhalom késö neolitikus kö leleteinek komplex, háztartás alapú elemzése, Budapest: s.n.

FÜZESI, A., 2009.

A neolitikus településszerkezet mikroregionális vizsgálata a Tisza mentén Polgár és Tiszacsege között. Mikroregionale Untersuchung des neolithischen Siedlungssystems entlang der Theiß zwischen Polgár und Tiszacsege. Tisicum, 19. kötet, pp. 377-398.

FÜZESI, A., 2016.

The settling of the Alföld Linear Pottery Culture in Szabolcs-Szatmár-Bereg county. Dissertationes Archaeologicae, 3(4), pp. 369-393.

FÜZESI, A., 2018.

Tiszalök-Hajnalos: new evidences for Neolithic masks in the Carpathian Basin. In: M. Nagy L. \& K. Szőlősi L., eds. "To Make a Firy Whistle from a Briar Rose." Studies Presented to Eszter Isztvánovits on Her 60th Birthday. Nyíregyháza: Jósa András Múzeum, pp. 49-63.

Füzesi, A., Mesterházy, G., Serlegi, G., Márkus, G., \& Raczky, P., 2016.

Polgár-Csőszhalom. Results of the new multidisciplinary investigations of a Late Neolithic settlement in the Tisza region. Hungarian Archaeology, 5(3), pp. 1-13. 
András Füzesi • Interaction between Landscapes and Communities in the Neolithic

GÁl, E., JuHÁsz, I. \& SÜMEgi, P. EDS., 2005.

Environmental archaeology in North-Eastern Hungary. Budapest: Institute of Archaeology of the Hungarian Academy of Siences.

Gosden, C. \& Malafouris, L., 2015.

Process archaeology (P-Arch). World Archaeology, 47(5), pp. 701-717. doi: http://dx.doi.org/10.1080/004 $\underline{38243.2015 .1078741}$

Gronenborn, D. \& Petrasch, J. eds., 2010.

Die Neolithisierung Mitteleuropas. The Spread of Neolithic to Central Europe. Mainz: Verlag des RömischGermanischen Zentralmuseums.

GYULAI, F., 2010.

Archaeobotany in Hungary. Seed, Fruit, Food and Beverage Remains in the Carpathian Basin from the Neolithic to the Late Middle Ages. Budapest: Archaeolingua.

HoDDER, I., 2012.

Entangled: An Archaeology of the Relationships Between Humans and Things. Chichester: Wiley-Blackwell. doi: http://dx.doi.org/10.1002/9781118241912

INGOLD, T., 1993.

The temporality of the landscape. World Archaeology, 25(2), pp. 152-174. doi: http://dx.doi.org/10.1080/0 $\underline{0438243.1993 .9980235}$

KaLla, G., 2013.

A háztartások régészete mint kutatási probléma. Household archaeology as a research problem. $\mathrm{M} \Omega \mathrm{MO} \Sigma$ VII. Öskoros Kutatók VII. Összejövetele 2011. március 16-18. Százhalombatta, Matrica Múzeum. Ösrégészeti Levelek - Prehistoric Newsletter, Volume 13, pp. 9-36.

KNAPPETT, C., ed., 2013.

Network Analysis in Archaeology. New Approaches to Regional Interaction. Oxford: Oxford University Press. doi: http://dx.doi.org/10.1093/acprof:oso/9780199697090.001.0001

KoHler, T., 2012.

Complex Systems and Archaeology. In: I. Hodder, ed. Archaeological Theory Today. 2nd ed. Cambridge: Polity Press, pp. 93-123.

KovÁcs, K., 2013.

A tiszai kultúra településtörténetének, belsö kronológiájának és kapcsolatrendszereinek vizsgálata Északkelet-Magyarországon. The settlement pattern, chronology and cultural relations of the Tisza Culture in Northeast Hungary, Budapest: s.n.

Kovács, K., 2013 b.

Late Neolithic Exchange Networks in the Carpathian Basin. In: A. Anders, et al. eds. Moments in Time. Papers Presented to Pál Raczky on His 60th Birthday. Budapest: Eötvös Loránd University - L'Harmattan, pp. 385-400.

KozŁowski, J. K., ED., 2009.

Interactions between different models of neolithization north of the central european agro-ecological barrier. Papers presented on the symposium organized by the EU Project FEPRE. Krakow: Polish Academy of Arts and Sciences. 
András Füzesi • Interaction between Landscapes and Communities in the Neolithic

L. HAJdú, M., 2014.

Újabb késő neolitikus lelőhelyek Borsod-Abaúj-Zemplén megyében. Newly discovered Late Neolithic archaeological sites in Borsod-Abaúj-Zemplén county, Hungary. A Herman Ottó Múzeum Évkönyve, Volume 53, pp. 67-101.

Magyari, E., JaKab, G., Bálint, M., Kern, Z., Buczkó, K., \& Braun, M., 2012.

Rapid vegetation response to Lateglacial and early Holocene climatic fluctuation in the South Carpathian Mountains (Romania). Quaternary Science Reviews, Volume 35, pp. 116-130. doi: https://doi.org/10.1016/j. quascirev.2012.01.006

MAKKAY, J., 1982.

A magyarországi neolitikum kutatásának új eredményei. Az időrend és a népi azonositás kérdései. Budapest: Akadémiai Kiadó.

Moskal del Hoyo, M. eT AL., 2018.

The character of the Atlantic oak woods of the Great Hungarian Plain. Quaternary International, Volume 463, pp. 337-351. doi: https://doi.org/10.1016/j.quaint.2017.02.029

MülLER, J., 2018.

Landscape and the GSHDL 20072017: Ten Years of Research. In: A. Haug, L. Käppel \& J. Müller, szerk. Past Landscapes. The Dynamics of Interaction between Society, Landscape and Culture. Leiden: Sidestone Press, pp. 17-36.

Orton, C., Tyers, P. \& Vince, A., 1995.

Pottery in Archaeology. Cambridge: Cambridge University Press.

Pechtl, J., 2015.

Linearbandkeramik Pottery and Society. In: C. Fowler, J. Harding \& D. Hofmann, eds. The Oxford Handbook of Neolithic Europe. Oxford: Oxford University Press, pp. 555-572. doi: https://doi.org/10.1093/ oxfordhb/9780199545841.013.061

RaAB, M. L. \& Goodyear, A. C., 1984.

Middle-range theory in archaeology: A critical review of origins and applications. American Antiquity, 49(2), pp. 255-268. doi: https://www.doi.org/10.2307/280018

RACZKY, P., 2006.

House structures under changes on the Great Hungarian Plain in earlier phases of the Neolithic. In: N. Tasić, ed. Homage to Milutin Garašanin. Belgrade: SASA, pp. 379-398.

RACZKY, P., 2015.

Settlements in South-East Europe. In: C. Fowler, J. Harding \& D. Hofmann, eds. The Oxford Handbook of Neolithic Europe. Oxford: Oxford University Press, pp. 235-253. doi: https://doi.org/10.1093/ oxfordhb/9780199545841.013.061

RACZKY, P. \& ANDERS, A., 2003.

The internal relations of the Alföld Linear Pottery culture in Hungary and the characteristics of human representation. In: E. Jerem \& P. Raczky, eds. Morgenrot der Kulturen Frühe Etappen der Menschheitgeschichte in Mittel- und Südosteuropa Festschrift für Nándor Kalicz zum 75. Geburtstag. Budapest: Archaeolingua, pp. 155-182. 
András Füzesi - Interaction between Landscapes and Communities in the Neolithic

RACZKY, P. \& ANDERS, A., 2009.

Settlement history of the middle Neolithic in the Polgár micro-region (the development of the Alföld linearband pottery in the Upper Tisza region, Hungary). In: J. K. Kozłowski, ed. Interactions Between Different Models of Neolithization Norh of the Central European Agro-Ecological Barrier. Krakow: Polish Academy of Arts and Sciences, pp. 31-50.

RACZKY, P. \& ANDERs, A., 2012.

Neolithic enclosures in Eastern Hungary and their survival into the Copper Age. In: H. Meller \& F. Bertemes, eds. Neolithische Kreisgrabenanlagen in Europa. Neolithic Circular Enclosures in Europe. Internationale Arbeitstagung 7.-9. Mai 2004 in Goseck (Sachsen-Anhalt). Halle: Landesamt für Denkmalpflege und Archäologie, pp. 271-309.

RaczKy, P., Anders, A., SeböK, K., Csippán, P., \& Tóth, Z., 2015.

The times of Polgár-Csőszhalom. Chronologies of human activities in a late Neolithic settlement in Northeastern Hungary. In: S. Hansen, P. Raczky, A. Anders \& A. Reingruber, eds. Neolithic and Copper Age between the Carpathians and the Aegean Sea. Chronologies and Technologies from the 6th to the 4th Millenium BC. Bonn: Rudolf Habelt Verlag, pp. 21-48.

Raczky, P., Meier-Arendt, W., Anders, A., Hajdú, Z., Nagy, E., Kurucz, K., Domboróczki, L., SebőK, K., SÜmegi, P., Magyari, E., 2002.

Polgár-Csőszhalom (1989-2000): Summary of the Hungarian-German excavations on a Neolithic settlement in Eastern Hungary. In: R. Aslan, et al. eds. Mauerschau: Festschrift für Manfred Korfmann. Grunbach Remshalden: Verlag Bernhard Albert Greiner, pp. 833-860.

SEBÖK, K., 2018.

On the possibilities of interpreting Neolithic pottery. Az újkőkori kerámia értelmezési lehetőségeiről. Dissertationes Archaeologicae, 3(6), pp. 13-42.

SeböK, K., Faragó, N., Hajdú, Z., Anders, A., \& Raczky, P., 2013.

Egy különleges kút és leletei Polgár-Csőszhalom késő neolitikus településéről. Archaeologiai Értesitö, 138(1), pp. 29-79. doi: https://doi.org/10.1556/archert.138.2013.2

SHERRATt, A., 1982.

The development of Neolithic and Copper Age settlement in the Great Hungarian Plain Part I: The regional setting. Oxford Journal of Archaeology, 1(3), pp. 287-316. doi: https://doi.org/10.1111/j.1468-0092.1982. $\underline{\mathrm{tb} 00315 . \mathrm{x}}$

SiKLósi, Z., 2013.

Traces of social inequality during the Late Neolithic in the Eastern Carpathian Basin. Budapest: Institute of Archaeological Sciences, Eötvös Loránd University.

Strobel, M., 1997.

Ein Beitrag zur Gliederung der östlichen Linienbandkeramik. Versuch einer Merkmalanalyse. Saarbrücker Studien und Materialen zur Altertumskunde, Volume 4-5, pp. 9-98.

Vita-FinZi, C. \& Higgs, E. S., 1970.

Prehistoric economy in the Mount Carmel area of Palestine: Site catchment analysis. Proceedings of the Prehistoric Society, Volume 36, pp. 1-37. doi: http://dx.doi.org/10.1017/S0079497X00013074 
András Füzesi • Interaction between Landscapes and Communities in the Neolithic

VÖRÖs, I., 1995.

Animal husbandry in the Middle Neolithic settlement at Tiszavasvári-Deákhalmi dülö (Upper Tisza region). Állattartás és vadászat Tiszavasvári-Deákhalom középső neolitikus településén.. A Jósa András Múzeum Évkönyve, Volume 36, pp. 167-184.

Washburn, D. K. \& Crowe, D. W., 1988.

Symmetries of Culture. Theory and Practice of Plane Pattern Analysis. London: University of Washington Press.

Wurzer, G., Kowarik, K. \& Reschreiter, H., 2015.

Agent-based Modeling and Simulation in Archaeology. Cham: Springer. doi: https://www.doi. org/10.1007/978-3-319-00008-4 